\title{
COVID-19 Pandemisinde Yumușak Güç Kavramının ve İlgili Tıbbi Terminolojinin Etik Olarak Deg̃erlendirilmesi
}

\section{Ethical Evaluation of the Concept of Soft Power and Related Medical Terminology in the COVID-19 Pandemic}

\author{
Çag̃atay ÜSTÜN'(iD), Seçil ÖzçiFTçiz(IiD)
}

\footnotetext{
${ }^{1}$ Ege Üniversitesi Tıp Fakültesi, Tıp Tarihi ve Etik Anabilim Dalı, İzmir, Türkiye

2 İzmir Kâtip Çelebi Üniversitesi Tıp Fakültesi, Tıp Tarihi ve Etik Anabilim Dalı, İzmir, Türkiye
}

\begin{abstract}
Makale atıfı: Üstün Ç, Özçiftçi S. COVID-19 pandemisinde yumuşak güç kavramının ve ilgili tıbbi terminolojinin etik olarak değerlendirilmesi. FLORA $2021 ; 26(3): 345-52$
\end{abstract}

\section{ÖZ}

2019 yılının Aralık ayında Çin'in Hubei eyaleti Wuhan kentinde ortaya çıkan ve kısaca COVID-19 olarak tanımlanan viral bir hastalığın kısa sürede pandemi şekline dönüşmesi tüm dünyada tıbbi, ekonomik, sosyal, etik dengeleri derinden etkiledi. Yaklaşık bir yıl geçmesine rağmen bu hastalığın etki gücünün artırmaya devam etmesi ve yeni mutant türlerinin ortaya çıkması bu konudaki endişeyi daha da artırmaktadır. Hastalığa ait spesifik bir tedavi protokolü oluşturma çalışmaları devam ederken, hastalığın farklı ülkelerde aşılarının bulunarak kullanıma sunulması aşı odaklı bir yaklaşımı ortaya çıkardı. Bir süre sonra aşı üreten ülkeler ile aşıyı satın alarak kullanacak ülkeler arasındaki bağlantının belli noktalarında gündeme gelen yumuşak güç kavramı COVID-19 pandemisine farklı bir boyut kattı. Yumuşak güç ilk kez Joseph Nye tarafından 1990 yılında bulunarak kullanılmış bir terimdir. Geleneksel güç söyleminden farklı bir anlamı olan bu kavram ortaya atıldıktan kısa bir süre sonra akademisyenler ve politikacılar tarafından gündelik dilde kullanılmaya başlandı. Son yıllarda güç ve etkinin birbirine bağlanmasılla bu kavram belirgin bir amaca yönelerek yeni bir etkileme anlayışına dönüşmüştür. COVID-19 pandemisinde yeni aşıların bulunmaya başlamasıyla gözlemlenen aşı diplomasisi bu anlayışın bir tanesidir. Aşı diplomasisinin bir tür yumuşak güç şeklinde kullanılarak ülkeler arası iletişimlerin sınırlarına dahil edilmesiyle yeni dengelerin COVID-19 üzerinde oluştuğu görülmektedir. Bu çalışmada COVID-19 pandemisiyle gündeme gelen yumuşak güç ve bunun devamında ortaya çıkan aşı diplomasisi güncel kaynaklardan yararlanarak etik açıdan değerlendirilmeye çalışılmıştır. Bu süreçte yumuşak gücün COVID-19 aşıları üzerinden sağladığı etkiyi gözlemlemek farklı değerlendirmelerde bulunmamıza olanak tanıyacaktır.

Anahtar Kelimeler: COVID-19; Yumuşak güç; Aşı diplomasisi; Tıp; Etik 


\title{
ABSTRACT \\ Ethical Evaluation of the Concept of Soft Power and Related Medical Terminology in the COVID-19 Pandemic
}

\author{
Çag̃atay ÜSTÜN', Seçil ÖZÇiFTÇi²
}

${ }^{1}$ Department of History of Medicine and Ethics, Ege University Faculty of Medicine, İzmir, Turkey

${ }^{2}$ Department History of Medicine and Ethics, İzmir Kâtip Çelebi University Faculty of Medicine, İzmir, Turkey

\begin{abstract}
Since its turn into a pandemic in a short time, a viral disease described as COVID-19 which emerged in Wuhan, Hubei has deeply affected the medical, economic, social and ethical balances all over the world. Even though it has been more than a year, the continuation of the potency of the disease and the emergence of new mutant strains further increase the concern over this issue. While efforts to create a specific treatment protocol for the disease are continuing, the availability of vaccines in different countries for the disease has led to a vaccine-focused approach. After a while, the concept of soft power, which came to the fore at certain points of the connection between the countries that produce the vaccine and the countries that will buy the vaccine, added a different dimension to the COVID-19 pandemic. The concept of 'soft power' was first introduced and used by Joseph Nye in 1990. This concept, which has a different meaning from the traditional discourse of power, started to be used in everyday language by academicians and politicians shortly after it was first used. With the interconnection of power and influence in recent years, this concept has turned into a new perspective for influence due to its turn towards a specific purpose. The vaccine diplomacy observed with the development of new vaccines for the COVID-19 pandemic is one of these perspectives. It is observed that new balances are built on COVID-19 by using vaccine diplomacy as a kind of soft power and including it within the borders of inter-country communication. In this study, the soft power which came into existence over Covid-19 and vaccine diplomacy that emerged due to the soft power were tried to be evaluated by using up-to-date sources. Observing the effect of this soft power on COVID-19 vaccines in this process will allow us to make different evaluations.
\end{abstract}

Key Words: COVID-19; Soft power; Vaccine diplomacy; Medicine; Ethics

\section{GíRiș}

Yeni koronavirüs salgınının tüm dünyayı bir dönüm noktasına getirdiği görülmektedir. Bu hastalığın vakası ilk olarak Aralık 2019'un sonlarında Wuhan'da kayıtlara geçti. Hastalıkla ilgili bulașıc1lığın artması üzerine Dünya Sağlık Örgütü (DSÖ) tarafından 30 Ocak 2020'de koronavirüs salgını uluslararası öneme sahip acil bir halk sağlığı durumu olarak ilan edildi. DSÖ Genel Direktörü 11 Mart 2020'de bunun bir pandemi olarak kabul edildiğini açıkladı. COVID-19 salgını, sadece dünyadaki sağlık sisteminin yetersizliğini ortaya çıarmakla kalmadı, aynı zamanda büyük güçler açısından dünya hegamonyasına yönelik jeopolitik bir tartıșmayı da tetikledi ${ }^{[1]}$.

Bu hastalığın 2019 yılının Aralık ayından önce de var olup olmadığına ilișkin soru ișaretleri halen zihinleri mesgul etmekle birlikte bununla ilgili henüz doğrulayıcı bir kanıta rastlanmadı.

Araștırmacılar viral etkenli bu hastalığın 1960 yıllarında Uluslararası Virüs Taksonomisi Komitesi (International Committee on Taxonomy of Viruses) bünyesinde alt calıșma grubu Koronavirüs
Calıșma Grubu (The Coronavirus Study Group) tarafından belirlenen koronavirüs (CoV) grubundan olduğunu belirterek, virüsü SARS-CoV-2 seklinde nitelendirilmiș, daha sonra Dünya Sağllk Örgütü (DSÖ) tarafından bu virüs kısaca COVID-19 olarak adlandırılmıștır ${ }^{[2,3]}$.

Halen bir pandemi olarak dünyadaki etkisini devam ettiren ve İngiliz varyantı (B.1.1.7), Güney Afrika varyantı (B.1.351), Brezilya varyantı (VOC202101/02 (P.1) ve VUI202101/01), Hindistan varyantı (B.1.617) gibi isimlerle anilan mutant türlerinin artmasıyla bu hastalığın ne zaman ve nasıl sönümleneceği hususundaki belirsizliğin devam ettiği görülmektedir ${ }^{[4,5]}$.

COVID-19'a yönelik spesifik bir tedavi protokolü üzerinde yapilan calıșmalar devam etmekle birlikte, farklı ülkelerde bulunmaya bașlanan așların varlığı hastalığın önlenmesine yönelik umutların artmasına sebep olmaktadır.

Yapılmaya devam edilen klinik calıșmalar sonucunda 79 așı (22'si son deneme veya onay așamasında, 13'ü ise en az bir ülkede kullanım için) onaylanmıștır. Bunlar arasında geliș- 
tirilen ve dağıtımda olanlardan dört tanesi Avrupa ve Amerika Birleșik Devletleri'nde (Pfizer/ BioNTech, Moderna, Oxford/AstraZeneca, Johnson \& Johnson), iki tanesi Rusya'da (Sputnik V ve FBRI), beș tanesi Cin'de (SinoVac, CanSino, iki tanesi Sinopharm ve ZF2001) ve iki tanesi Hindistan'da (Covishield, yerel olarak üretilen Oxford/AstraZeneca așısı ve Covaxin) olarak bilinmektedir ${ }^{[6]}$.

COVID-19 așılarının bulunmasının ardından ortaya cıkan bir bașka sorun, bu așı1 bulan ülkelerle bu așııı satın alarak kullanan ülkeler arasında gelișmeye bașlayan yumuşak güc kavramının belirginleșmesi ve diplomatik alanlardaki etkinliğinin artmaya bașlamasıdır.

\section{Yumușak Giiç ("Soft Power")}

Güc, kișinin istediği sonuçları elde etmek için bașkalarını etkileme yeteneğidir. Bunun bașarılmas1 zorlama, ikna, cazibe olușturma gibi yöntemlerin kullanılmasıyla sağlanabilir. Yumușak güç ("soft power") ise baskı yapılmadan cekim etkisinden yararlanarak istenilen sonucları elde etme yeteneğidir. Yumusak güc terimi ilk kez Joseph Nye'nin 1990 tarihli [Bound to Lead The Changing Nature of American Power (Liderliğe Mecbur: Amerikan Gücünün Değișen Doğası)] isimli kitabında kullanılarak, güc kavramının geleneksel görüșlerine karș1 cıkan bir pozisyonda ortaya c1ktı ${ }^{[7]}$.

Nye'nin bulduğu yumușak güç kavramı sayesinde zorlamanın etkisinin önemini yitirdiŏi görülmektedir. Nye, kültürel ve ideolojik bilgi birikiminin karșllkkl bir iletișim gücü ortaya çkararak ortaklasa bir güc sayesinde bağımlılık olușturduğunu ileri sürmüștür. Nye, yumușak gücü kavramsallaștırdıktan sonra sert gücü ekonomik anlamda tanımlar ve tehditlere dayanan askeri gücün bunun yanında değerlendirilmesi gerektiğini belirtir. Ona göre gücün soyut olan ikinci yüzünü olușturan yumușak güc, bașkalarının tercihlerini sekillendirme yeteneğidir. Diğer bir deyișle yumușak güc çekiciliğe dayanan bir durumdur ve kültür, politik değerler, dıș politika gibi üç farklı kaynaktan beslenir ${ }^{[8,9]}$.

Nye'ye göre yumușak güc kültuirel bir güc olarak değerlendirilebilir. Ancak ona göre yumușak gücün ekonomik bir gücle özdeșlestirilmesi doğru değildir ve güç kavramına katılan yumușak ibaresinin ise daha insancıl olduğunu iddia etmek zordur. Nye, yanlıs ellerdeki yumușak gücün korkunç sonuçları varmıș gibi gözükse de bazı durumlarda belirli hedefler için ahlaki anlamda daha üstün veriler sunabildiğini söylerken, Mohandas (Mahatma) Gandhi veya Martin Luther King Jr.'ın uyguladığı yumuşak gücün zaman içinde 1lımlı coğunluğu cekmeyi bașardığını ve sonuçlar açısından etkinlik ve etik açıdan etkileyici olduğunu örnek verir ${ }^{[10]}$ Joseph Nye yumușak gücün bașka bir tanımını şöyle yapmıștır: "İstediğini, zor kullanmak veya para vermek yerine kendine cekme yoluyla elde etme becerisidir" "11]

Soğuk savaș yıllarının ardından sert güc kavramı yerini yumușak güçle değiștirmeye bașlamıștır. $\mathrm{Bu}$ sayede geliștirilen kamu diplomasisinin merkezini yumușak güç olușturmuștur.

Kamu diplomasisi; temel olarak yumușak güc, diplomasi, kamuoyu ve sivil toplum arasındaki ilișkilere dayanmaktadır ve bu durum onu, "yeni bir diplomasi sanatı" haline dönüștürmektedir [12]

\section{Yumușak Giiç ve Tıp}

Soğuk Savaș Dönemi'nin sona ermesiyle yeni sorunların, yeni aktörlerin ortaya cıkması nedeniyle yumușak güc kavramının farklı alanlar üzerinden etkinliğini sürdürdüğünü biliyoruz. Bunlardan bir tanesi de tıptır. Yumușak gücün tıpta kullan1mı, tıbbın tarafsız ve yașam değerleriyle örtüșen yanlarının bulunması sebebiyle tercih edilmektedir. Böyle politik diplomasisinden daha etkin bir alanın aracılığıyla belli kaygıların giderilmesi mümkün hale gelmektedir.

Dünya Sağlık Örgütü, küresel sağlık diplomasisini, olumlu değișimi yönetmek ve sekillendirmek için bir araç olarak halk sağlığı, uluslararası ilișkiler, yönetim ve hukuk disiplinlerinden yararlanmak yeteneği seklinde tanımlamaktadır. Tarihsel anlamda, sağlık diplomasisi insani yardım amacı doğrultusunda ortaya cılkmıștır. Bu kavram hükümetler tarafından kamu yararı için bașkalarının davranıșlarını olumlu yönde etkilemek için daha fazla kullanılmakta ve yumușak güc olarak anımsanmaktadir ${ }^{[13]}$.

Tıp aracılığıyla yumușak güç kavramının bütünleștiği öykülerden önemli bir tanesi "Hope (Umut)" projesi kapsamında Amerika Birleșik Devletleri (ABD)'nin dünyanın dört bir yanındaki tıbbi bakıma muhtac hastalara yardım etmek için hazırlanmış ABD donanmasına ait bir geminin 
hastaneye dönüștürülmesiyle ortaya cıkmıștır. Projenin tasarımcısı Dr. William B. Walsh "Dünyanın her yerindeki topluluklara sağlık eğitimi ve iyileștirilmiș bakım getirecek yüzen bir tıp merkezi" hayalini gerçeğe dönüștürmeyi bașardı. Bu fikrini ABD bașkanı Dwight D. Eisenhower ile paylaștığında "Amerikalıları anlamayan ve Amerikalıları sevmeyen cok sayıda insan var." fikrinden hareket ettiğinden bahsetti. 1958 yilında bașlayan proje 1974 yılında sona erdiğinde toplamda, yaklașık 200.000 hastanın ceșitli rahatsılıkları tedavi edilirken, yaklașı 19.000 büyük ameliyat gerçekleștirilirdi. Gemide proje süresince 2500 kadar hekim, hemșire ve sağlık personeli hizmet verdil ${ }^{[14]}$.

Günümüzde yumușak güç kavramının bir sağlik diplomasisinin içinde kendisine yer bulmasının ardından, COVID-19 pandemisi için așı geliștirme çalısmalarının hız ve etkinlik kazanmasıyla bunun bir așı diplomasisine dönüșme olasılığı olduğunu kabul etmek gerekir.

\section{COVID-19 Așılarıyla Gelișen Yumușak Giic Kavramı}

Bugün COVID-19'a karșı așı geliștirme calıș- malarında önemli așamalar kaydedilmiștir. Așının bu hastalıktaki önemli rolü kitle bağıșılı̆̆̆ının bir an önce olușturulmasına yöneliktir. Așlların bulunmasıyla doğal olarak yumușak güç kavramının öne çıktığı görülmektedir.

Yumușak güc teriminin etkinlik alanı kapsaminda ülkelerin sağlık sistemlerinin ve sağlık politikalarının da önemi vardır. Bireysel sağlık harcamaları ve buna ayrılan payların dengeli dağıtılması ve dünyanın genel sağlık anlayıșının yumușak güc ile ilișkilendirilebilecek yönlerinin bulunması muhtemeldir. Dünya çapında etkili bir bulașıc1 hastalığın sürveyansında uluslararası diplomasiyi etkileyebilecek kadar geniș sonuçların ortaya çkması kaçınılmazdir ${ }^{[15] .}$

Modern tarihte COVID-19 salgınında olduğu kadar acil bir așı geliștirme dürtüsü olmamıștır. COVID-19 pandemisine yönelik geliștirilen așlarda ülkelerin araștırmaları desteklemek için yatırım yaptıkları görülmektedir. Bașarılı bir așının bulunmasının yanında bunun toplu olarak üretilmesi ve eșit bir sekilde dağıtılmasının yolları sorusu cevapsız kalmaktadır. Burada düsüuk gelirli ülkelerin mali kaynak yetersizliklerinin pandemiyi önlemedeki en-

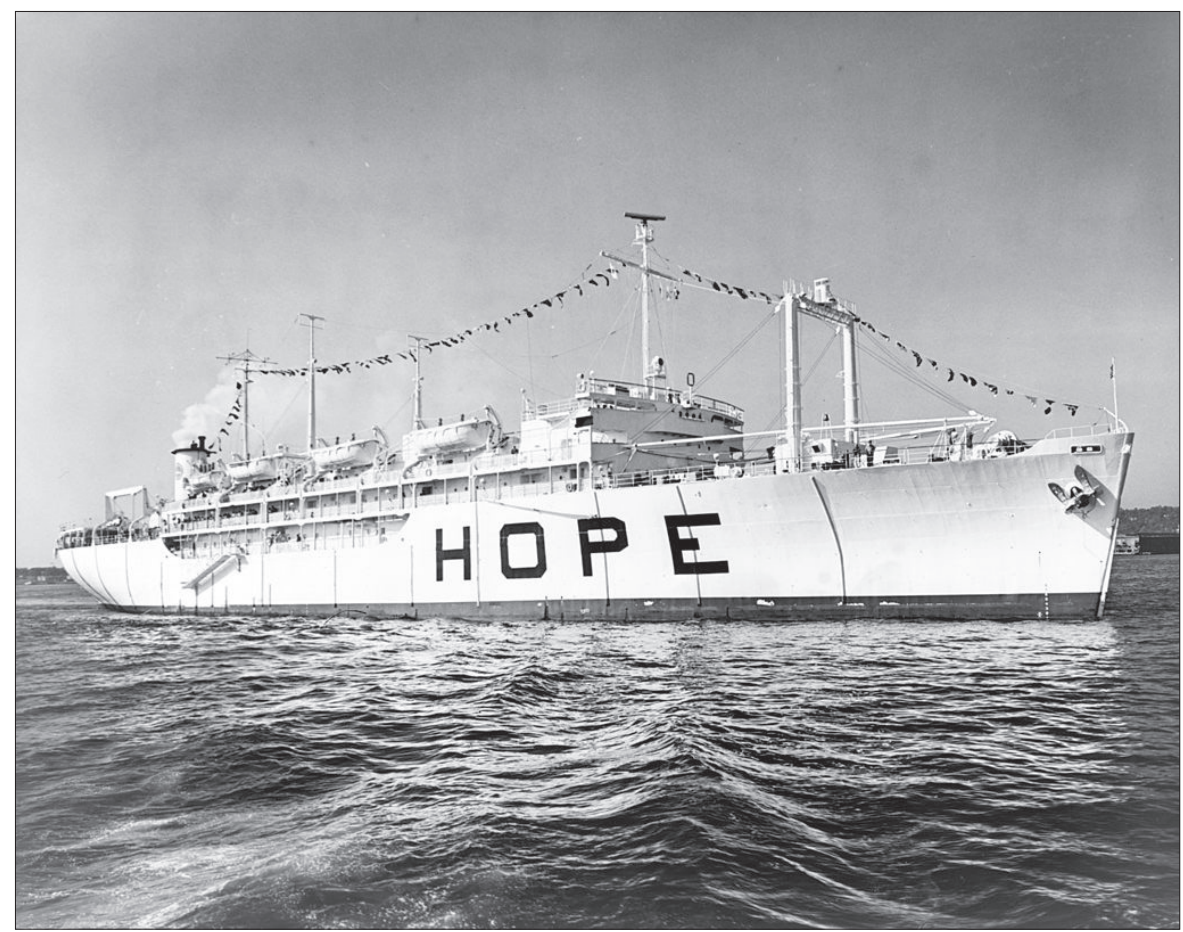

Resim 1. Hope Projesi kapsamında hastaneye dönüştürülen gemi. Bu proje yumuşak güç kullanımının tıpla olan bağlantısını bir örneğiydi (https://en.wikipedia.org/wiki/Project_HOPE\#/ media/File:S_S_Hope.jpg). 
gellerden birisini olușturmaktadır ${ }^{[16]}$.

Oysaki, 24 Nisan 2020'de Dünya Sağllk Örgütü, insani yardım ve özel sektör kurulușlarıyla ortaklașa, "güvenli, kaliteli, etkili ve uygun fiyatl COVID-19 teshis, tedavi yöntemlerine ve așlara adil küresel erișim taahhüdünü teyit etmiști ${ }^{[17]}$

2019 yılında yeni viral pandeminin çıtığı ülke olarak kabul edilen Çin, aynı zamanda bu hastalığı yenen ilk ülkeydi. Salgını kendi içinde kontrol ettikten sonra Cin'de koronavirüs diplomasisi denilen bir tür kamu diplomasisi oluștu. Kısaca Cin'in COVID-19 salgınıyla ilgili olarak yürüttüğu uluslararası iletișim iki așamada incelenebilir: Bunlardan ilki Çin'in bu hastalığı ülke içinde nasıl ele aldığıyla ve önlemleriyle, ikincisi ise diğer ülkelere sağladığı yardımla ilgilidir. Çin'in yüksek vaka oranları ve önlemlerle uğrașan diğer ülkelere bu konuda yaptığı bilgi paylașımları ve yardımlar yumușak güc kavramı ile birlikte değerlendirildi. COVID-19 pandemisi dünyada ikinci dalgasını sonbahar 2020'de yaparken, Çin'deki koronavirüs diplomasisi Çin'in bulduğu assının da etkisiyle yerini așı diplomasisine biraktıl ${ }^{[18]}$.

Artık COVID-19 așlarının geliștirilme sürecinde bulunduğumuz bir dönemde bunun bir tür aș diplomasisine dönüșme olasılığı vardır. Bu sayede uluslararası güveni ve ișbirliğini güçlendirmeye ihtiyaç olduğu görülmektedir. Böylece gelecekte yașanabilecek yeni salgınlar ve pandemilerde doğru adımların atılması sağlanabilir. Ancak yașanan güc dengesizlikleri de görmezden gelinemez. Bir tarafta COVID-19 așı dozlarını satın alan yüksek gelirli ülkeler ile diğer tarafta düșük gelirli ve COVID-19 așı dozlarını beklemekte olan ülkelerin varlığı bir celișki olușturmaktadır ${ }^{[19]}$.

Uzmanların hemfikir olduğu konu, birçok devletin kendi ulusal, COVID-19 așlarını üretme ve dünyaya dağıtma cabaları, yeni bir jeopolitik ve yumușak güc rekabeti biçimini harekete geçirmektedir.

"Hızlı ilerleyen bir pandemide, herkes güvende olmadığı sürece kimse guivende değildir." sloganıyla hareket eden Dünya Sağlık Örgütü, bir așı diplomasisi olușturmak için COVAX ${ }^{[20]}$ sistemi üzerinden COVID-19 așlarına her ülkenin eșit erișim sansını desteklemek amacına yönelik calıșmaktadır. Bilindiği gibi mali açıdan zengin ülkeler bu erișim sansının kendi ülkelerine yönelik olması için caba sarf etmektedirler. Mevcut dozların bu ülkelerin kendi nüfuslarını așılamak için kullanması așı milliyetçiliği diye tabir edilen bir bașka sonuca yol açmıștır ${ }^{[21]}$.

Geliștirilen bir COVID-19 așısının ülkeler arasında adil bir sekilde dağıtılması, adaletli bir dağıtımın gereğidir. Așının ilk alıcıları hükümetler olacak olsa da, ülkeler arasında yapilacak adil dağıtım, bundan yararlanacak bireyler için ahlaki bir endișeyi yansıtmalıdır. Burada etik açıdan üc temel değerin göz önünde bulundurulması gerekmektedir: insanlara fayda sağlamak ve zararı sinırlamak, dezavantajllara öncelik vermek ve eșit ahlaki ilgi olușturmak ${ }^{[22]}$.

Son zamanlarda gelișen așı diplomasisinin yumușak güçle olan bağlantısı incelendiğinde, așı üreten ülkelerden birisi olan Hindistan'ın AstraZeneca așısının versiyonunu komșusu olan Myanmar, Banglades, Nepal, Sri Lanka ve Maldivler'e dağıtma sözünü 20 Ocak 2021'de vermesi "Așlar Yoluyla Dostluk (Friendship Through Vaccines)" olușturma seklinde isimlendirilen bir kamu diplomasisi olușturma arzusuyla hareket edilmesine güzel örnektir. Yașanacak bu benzeri durumlar yumușak güc hikayesinde yeni bir bölümün bașladığını göstermektedir ${ }^{[23]}$.

Bir bașka haberde ise, The New York Times yayın kuruluşunun açıklamasında, așıların sadece hastalıkları önleme araçları olmadığını, aynı zamanda ülkelerin düșük gelirli ülkelerde yumușak güc sağlama aracı olduğu belirtilerek, Hindistan, Cin ve Rusya gibi büyük așı üreticisi ülkelerin orta ve dưșük gelirli ülkelere așı dozu bağıșında bulunduğu duyurmuștur ${ }^{[24]}$.

Ülkelerin kendi asslama oranlarını güvence altına almak için uğraștıkları bir sırada küresel sözlüğe "așı milliyetçiliği", "așı yarıșı" gibi yanlıș ve çirkin kavramların girmesi bu konudaki iyi niyet çabalarını zora sokmaktadır. Bu süreçte farklı bir yaklașım sergileyen Hindistan, Așı Maitri (Vaccine Maitri-Așı Dostluğu) kampanyası kapsamında Oxford Úniversitesi ve AstraZeneca lisansı altında üretilen yüzbinlerce Hint yapımı Covishield așısını yaklașı 60 ülkeye gönderdi. Küresel așı üretiminin \%62'sinni karșlayan ve bir tür farmasötik güc merkezi olan bu ülkenin gergin ilișkileri düzeltmek için COVID-19 așısını yumușak güc olarak kullan- 
ması farklı bir yaklașım biçimi olarak kabul edildi. Hindistan'da düșük maliyetli COVID-19 așısı üretilmesinin bu așıyı almakta zorlanan düșük gelirli ülkelere fayda sağlayacağı düșünülmektedir. Ancak buradaki bir bașka celișkili nokta așı üreticisi konumundaki Hindistan'1n 8 Nisan 2021 itibariyle ülkesinde sadece 87.1 milyon kișiyi așlamıs olmasıdır ${ }^{[25,26]}$. Nüfusunun yaklașık 1.4 milyar olduğu da göz önüne alındığında bu ülkenin așlama oranının yetersiz olmasının ortaya çıkardığı çelișki dikkat cekicidir.

ABD tarafından bakıldığında ise, tüm nüfus için yeterli așının tedarik edildiği, Subat ayında Pfizer ve Moderna ile anlașmalar imzalanarak 600 milyona yakın doz așı sipariși verilmiștir. Buna ilave olarak 100 milyon doz Johnson \& Johnson așısının daha sipariș edildiği ve ayrıca Novavax ve AstraZeneca'dan da sipariș talebinde bulunulduğu bilinmektedir. Böylece $\mathrm{ABD}$ kendi nüfusunun tamamını așlamaya yetecek kadar doz așıya sahip olduğu görülmektedir. Bu așırı așı stoklamanın ABD'yi bir tür istifçi haline dönüștürdüğu söylenmektedir. Bunun da onu cesur liderlik rolünün gerisine düșürdüğüne ve diğer așı yoksunu ülkelere yapılacak yardımların uzağında tuttuğuna dikkat çekilmektedir $^{[27]}$.

COVID-19 așısı konusunda Çin ve Rusya'nın çabaları Avrupa Birliği'ne yumușak güc dersleri vermesi seklinde algılanmaktadır. Çin vatandașlarına ve 53 ülkeye ücretsiz așı sağlayan Pekin yönetimi erken așı teslimatları için düșük ve orta gelirli ülkeleri hedeflemektedir. Buna ilaveten Türkiye, Macaristan ve Sirbistan'a da așı temininde kolaylık sağlaması Çin'in așı diplomasisinin önünde yürüdüğünün göstergesidir. Rusya'nın Sputnik $\mathrm{V}$ așısı da Avrupa'da kabul görmeye bașladıktan sonra, Almanya'nın Bavyera'da üretilmek üzere 2.5 milyon doz așı için ön sipariș anlamasını imzalaması bu așıya olan güvenin artmakta olduğunun bir belirtisidir. Sputnik V așssıyla ilgilenen bir bașka ülke Fransa olmakla birlikte, Sirbistan ve Karadağ'a da bu așıdan teslimatların yapılması Rusya'nın așı diplomasisini geliștirme konusunda kararlı olduğunu göstermektedir ${ }^{[28]}$.

\section{Etik Değerlendirme ve Sonuç}

COVID-19 pandemisi bașlangıcı ve yayılımı açısından tüm dünyada tedirginlik ve endișeye sebep olmuștur. Bu bulașıcı viral hastalığın kısa sürede pandemi sekline dönüșmesi, ölümlerin görülmesi önemli bir sağlık sorununun bașladığını göstermiștir. Bașlangıçta hastalık 65 yaș ve üstü, kronik hastalığı olan gruplarda daha etkili olurken, bugün yeni mutantları sayesinde cocuk yas gruplarına kadar inen bir seyir gözlenmektedir. Su an için bu hastalıktan korunabilmek için ülkeler genelinde kitle bağıșıklığı olușturmanın ve geliștirilen așların uygulanmasının önemi ortadadır. Makalemizde ele aldığımız konuları etik açıdan değerlendirdiğimizde;

Uzun bir süredir siyaset ve politikalarda etkin olan yumușak güç kavramının sağlık alanı içine de dahil olduğu ve son bir yıldır etkin olan COVID-19 pandemisinde bu konunun gündeme geldiği, özellikle ülkeler arası ilișkilerde yumușak güce bassvurularak, ülkelerin birbiri üzerinde etkiler olușturmaya calıștığı gözlemlenmektedir. Buradaki etkinliğin geliștirilen așlar ve buna bağlı așı diplomasisiyle olduğu fark edilmektedir. Ortadaki bir bașka sorun ülkelerin așıya erișiminin kolaylaștırılmasına yönelik çalıșmaların yanında, hangi ülkenin ne kadar miktarda așıyı temin edeceğiyle de ilișkili hale gelmiștir. Bu noktada yüksek-orta-düsüu gelirli ülkeler arasındaki farkın açlması, așıya erișim olanakları dahilinde yașanabilecek etik sorunları artırmaktadır. Așıya erișebilen ülkelerin vatandașlarına așılama yapmasıyla sağlanacak bağıșılama programlarına orta ve düșük gelir grubundaki ülkelerin katılmasının gecikmesi nedeniyle pandeminin kısa sürede etkinliğini azaltması mümkün olmayacak gibi görünmektedir.

Makalemizde de değindiğimiz gibi, gelișen așı diplomasisinin ülkelerin birbiri üzerindeki çekim gücünü farklı yönde artıracağı düșünülmektedir. Henüz aşıa erișim konusunda atılan adımların zayıflığı da dikkate alındığında, așıyı elde etmekte ekonomik açıdan güçük yașayan ülkelerin belki yardımlarla belki de bazı kaynaklarını tahsis etmek seklinde bunu sağlamaları yine farklı etik sorunları beraberinde getirecektir. Bugün ülkelerin birbirleri üzerindeki hakimiyetlerini artırmaya yönelik devam eden COVID-19 așı temininin de zorlașması yumușak gücün sınırlarının ne kadar geniș olduğunu göstermektedir. Halen pandeminin devam ettiği bugünlerde așı üreten ülkelerin bile kendi toplumlarını așlamakta güçlük çekmesi ve 
kitle bağıșıklı̆̆ını sağlayamaması sonucunda hasta ve ölüm oranlarının yükselmesi etik açıdan bir bașka celișkili durumu özetlemektedir. Burada değerlendirilmesi gereken nokta; COVID-19 aşlarına erișimin sağlığa erișimle özdes olduğu ve bundan mahrum bırakılmanın etik ve ahlaki açıdan doğru olmadığı yönündedir.

Tibbın etik ilkeleri arasında yer alan yarar sağlama ile sağlıklı olma hakkının önündeki engellerin kaldırılması gerekmektedir. Özellikle COVID-19 pandemisinde bunun önemi zamanla daha iyi anlașlacaktır. Ülkelerin bu așamadan sonra sağllk politikalarını yumusak gücle birlestirerek bulașıcı viral bir hastalığa karșı alınacak önlemlerde olumlu adımlar atılmasını cabuklastırması lazımdır. Ancak geliștirilmekte olan așların gelecekte belli faz așamalarını tamamladıktan sonra dünya genelinin sağlığının korunması için her ülkeye eșit düzeyde ve adaletlilik ilkesine uygun bir yararının olup olmayacağı sorusunun cevabı șu an için belirsizdir.

Buradaki örneklerin ortak noktası küresel çaptaki eșitsizliklerin ortaya cıııı̣ı olarak görülebilir. Etik ilkelerin içindeki adaletlilik kavramı bu sorunların çözümüne yönelik argümanları ortaya koyabilir.

Belki bir süre sonra COVID-19 pandemisi etkisini azaltacaktır. Ancak bir sonraki salgının nerede ve ne zaman bașlayacağı bilinmezliğini korumaktadır. COVID-19 pandemisinden cıkarılması gereken derslerin insanlığın zihninde yer bulması, yașanmıs yanlıs tecrübelerin ve uygulamaların üzerinde tekrar düșünülmesinin aynı yanlıșların tekrar edilmesinin önüne geçeceğine inanıyoruz.

\section{ÇIKAR ÇATIȘMASI}

Yazarlar bu makale ile ilgili herhangi bir çkar catıșması bildirmemișlerdir.

\section{KAYNAKLAR}

1. Gauttam P, Singh B, Kaur J. COVID-19 and Chinese Global Health Diplomacy: Geopolitical Opportunity for China's Hegemony? 2020; 11(3); 318-40.

2. Umakanthan S, Sahu P, Ranade AV. Origin, transmission, diagnosis and management of coronavirus disease 2019 (COVID-19). Postgrad Med J 2020;96:753-8.

3. World Health Organization (WHO). Naming the coronavirus disease (COVID-19) and the virus that causes it. Available from: https://www.who.int/emergencies/ diseases/novel-coronavirus-2019/technical-guidance/ naming-the-coronavirus-disease-(covid-2019)-and-the-virus-that-causes-it (Accessed date: 5 Apr 2021).
4. Robinson I, Banerjee I, Leclézio A, Sathian B. COVID-19 and mutations a threat level assessment. Nepal J Epidemiol 2021;11(1):983-7.

5. Euronews. Indian COVID-19 variant detected in at least seven European countries: ECDC. Available from: https:// www.euronews.com/2021/04/28/indian-covid-19-variant-detected-in-at-least-seven-european-countries-ecdc (Accessed date: 5 Apr 2021).

6. Errighi L. COVID-19 and the Global Vaccine Race, IAI Commentaries, Issue: 21|19. Available from: https://www.iai. it/sites/default/files/iaicom2119.pdf (Accessed date: 5 Apr 2021).

7. Nye JS. Soft power: the origins and political progress of a concept. Palgrave Comm Feb 2017;3(1):17008.

8. Yukaruç U. A Critical Approach to Soft Power. BEÜ SBE Derg 2017;6(2):491-502.

9. Soft Power 30. What is Soft Power? Available from: https:// softpower30.com/what-is-soft-power/ (Accessed date: 2 Apr 2021).

10. Nye JS Jr. Think again: Soft Power, Foreign Policy, 22 Şubat 2006. Available from: http://www.foreignpolicy.com/articles/2006/02/22/think_again_soft_power (Accessed date: 2 Apr 2021).

11. Nye JS. Dünya Siyasetinde Başarının Yolu Yumuşak Güç ( Çev: Ri Aydın), Elips Kitap, Ankara 2005, 6.

12. Özerdem F, Barlas B. COVID-19 Salgınının Türk Kamu Diplomasisine Etkisi. Kırklareli Üniversitesi Iktisadi ve Idari Bilimler Fakültesi Dergisi 2021;10(1):73-98.

13. Divkolaye NSH. When health diplomacy serves foreign policy: use of soft power to quell conflict and crises. Disaster Medicine and Public Health Preparedness 2016;10(5):7247.

14. Soft Power Through Medicine: The Complicated History of Project HOPE. Available from: https://the-rotation. $\mathrm{com} /$ soft-power-through-medicine-the-complicated-history-of-project-hope/ (Accessed Date: 3 Apr 2021).

15. Donahue Jr HA. The Soft Power of Solid Medicine. World Medical \& Health Policy 2010;2(4):83-97.

16. Liu Y, Salwi S, Drolet BC. Multivalue ethical framework for fair global allocation of a COVID-19 vaccine. I Med Ethics 2020;46(8):499-501.

17. Worl Health Organiation (WHO). Commitment and call to action: Global collaboration to accelerate new COVID-19 health Technologies. Available from: https:// www.who.int/news-room/detail/24-04-2020-commitment-and-call-to-action-global-collaboration-to-accelerate-new-covid-19-health-technologies (Accessed date: $9 \mathrm{Apr}$ 2021).

18. Kobierecka A, Kobiereck MM. Coronavirus diplomacy: Chinese medical assistance and its diplomatic implications, International Politics 2021;8:1-18.

19. Pannu J, Barry M. The state inoculates: vaccines as soft power. Lancet (Published online: March 10, 2021) (Accessed date: 5 Apr 2021). 
20. World Health Organization (WHO). Available from: https:// www.who.int/initiatives/act-accelerator/covax (Accessed date: 5 Apr 2021).

21. Forland S, Sanka S. Shaping Soft Power in the Post-Pandemic World through "Vaccine Diplomacy". Feb 10, 2021. Available from: https://www.americansecurityproject.org/ will-vaccine-diplomacy-shape-soft-power-in-the-post-pandemic-world/ (Accessed date: 3 Apr 2021).

22. Ezekiel JE. An ethical framework for global vaccine allocation. Science 2020;369(6509):1309-12. Available from: https://science.sciencemag.org/content/369/6509/1309 (Accessed date: 9 Apr 2021).

23. Ellwood D. Vaccine Diplomacy: A New Chapter in the Story of Soft Power. Mar 17, 2021. Available from: https://uscpublicdiplomacy.org/blog/vaccine-diplomacy-new-chapter-story-soft-power (Accessed date: 5 Apr 2021).

24. Gobal Health Now. Vaccines Are the New Soft Power, Global Health Now, March 2, 2021. Avaialable from: https:// www.globalhealthnow.org/2021-03/vaccines-are-newsoft-power (Accessed date: 5 Apr 2021)

25. India's smart vaccine diplomacy, Shashi Tharoor, The Strategist. Available from: https://www.aspistrategist.org.au/ indias-smart-vaccine-diplomacy/ (Accessed date: 3 May 2021).
26. Sharun K, Dhama K. India's role in COVID-19 vaccine diplomacy. J Travel Med 16 Apr 2021.

27. Fortune. Unless the U.S. changes its vaccine policy, the world will look at us like hoarders, Kıslaya Prasad, Fortune. Available from: https://fortune.com/2021/04/04/us-vaccine-hoarding-nationalism-diplomacy-china-russia-india/ (Accessed date: 3 May 2021).

28. Leigh M. Vaccine diplomacy: soft power lessons from China and Russia? The Brugel Newsletter Available from: https://www.bruegel.org/2021/04/vaccine-diplomacy-soft-power-lessons-from-china-and-russia/ (Accessed date: 3 May 2021).

\section{Yazıșma Adresi/Address for Correspondence}

Ars. Gör. Secil ÖZCífTCுi

İzmir Katip Celebi Üniversitesi Tip Fakültesi,

Tip Tarihi ve Etik Anabilim Dal

İzmir-Türkiye

E-posta: ozciftcisecill@gmail.com 